\title{
The Effect of Scientific Approach Based on Tutorial Video on Students' Reading Comprehension of Procedure Text (A Quasi-Experimental Research at Grade VIII of SMPN 4 Kota Bengkulu)
}

\author{
Ahyauddin Ma'id \\ Azwandi \\ Arono \\ University of Bengkulu
}

\begin{abstract}
This research aimed to find out whether there was any effect of implementation scientific based approach using tutorial video on students' reading comprehension as a whole and various aspects in procedure text at grade VIII of SMPN 4 Kota Bengkulu. The design was a quasi-experimental research. The sample consisted of 50 students at grade VIII SMPN 4 Kota Bengkulu, 25 students for experiment group and 25 students for control group. The instrument was a reading test which comprised 50 multiple choice questions, the instrument was tried out with $r=0,970$. The research findings were as follows; (1) Scientific approach based on tutorial video affected students' whole reading comprehension; (2) scientific approach based on tutorial video affected students' reading comprehension in various aspects of reading comprehension, namely; finding general information, finding specific information, integrating information, and learning from text. Further study is recommended for other text types.
\end{abstract}

Key Words: Reading Comprehension, Scientific Approach, Tutorial Video

\begin{abstract}
Abstrak
Penelitian ini bertujuan mengetahui pengaruh pendekatan saintifik dengan menggunakan tutorial video pada kemampuan membaca dan berbagai aspek dalam prosedur teks pada kelas VIII SMPN 4 Kota Bengkulu. Desain penelitian ini yaitu kuasi eksperimen. Sampel penelitian ini, yaitu 50 siswa kelas VIII SMPN 4 Kota Bengkulu, 25 siswa untuk kelas eksperimen dan 25 siswa untuk kelas kontrol. Instrumen penelitian ini, yaitu tes membaca yang terdiri atas 50 pilihan ganda. Hasil penelitian ini, yaitu (1) pendekatatan saintifik menggunakan tutorial video mempengaruhi kemampuan membaca siswa secara menyeluruh; (2) pendekatatan saintifik menggunakan tutorial video mempengaruhi kemampuan membaca siswa pada aspek yaitu; menemukan informasi umum, menemukan informasi khusus, menggabungkan informasi, dan belajar dari teks. Kata Kunci: Kemampuan membaca, pendekatan saintifik, tutorial video
\end{abstract}

\section{INTRODUCTION}

As another language, English also has four skills to be acquired by the students. They are listening, reading, speaking and writing. It is not only for English as second language but also as foreign language. From those skills, reading is one of English skills in which the Standard of Competency stated that its purpose to comprehend many various meaning brought by the written text those objectives in 
communication, text structure and specific linguistic. It means that students need to be trained in order to have a good reading skill.

Reading is about understanding written texts. Learning to read is an important educational goal. For both children and adults, the ability to read opens up new worlds and opportunities. It enables us to gain new knowledge, enjoy literature, and do everyday things that are part and parcel of modern life, such as, reading the newspapers, job listings, advertisements, instruction manuals, maps and so on. According to Broek and Espin (2012), reading is defined as a cognitive process that involves decoding symbols to arrive at meaning. Reading is an active process of constructing meanings of words. Reading with a purpose helps the reader to direct information towards a goal and focuses their attention. Reading comprehension is a complex interaction among automatic and strategic cognitive processes that enables the reader to create a mental representation of the text.

Hence, reading activity has important role in language learning, in that sense of teaching reading, the teacher should consider among others likes; facilities, students background knowledge and method. To understand a text, the student must have good understanding on vocabulary of the target language, as learning a language does not mean merely learning word. Vocabulary proficiently will enable the student to acquire the skills of listening, speaking, reading, and writing. Reading becomes an important part of language teaching, and it has complicated problem. Some teachers considered that reading is not favorite activity for most students. Therefore, English teachers should find strategies to overcome this problem. They are expected to find appropriate strategies or activities to make students understand reading text and moreover enjoy reading.

Based on pre-observation at grade VIII of SMPN 04 Kota Bengkulu found some problems that related to learning process in reading. The first problem was students' poor of vocabulary. Vocabulary is important when learning languages including English, there are thousands of vocabulary. In many cases, even native speakers do not know all the words of the language. In fact, according to many sources the researcher have encountered, there are only some words that you must know to communicate in a language. Problem encountered in learning vocabulary or English vocabulary is that they learn new words. Second problem was students' lack of motivation to become an active readers. The motivation was required in learning language both internal or external motivation. The last problem was students' low score in reading comprehension. It was proven by the students' meanscore on mid test was 71,03. It was less than minimum standard score criterian which was 75,00 . However, these problems must be solved soon.

Since SMPN 4 Kota Bengkulu applied K-13 curriculum, scientific approach was implemented in every subject included English Subject. This aproach was also implemented by the English teachers in teaching reading for several text types. According to Modul pelatihan Pengembangan Kurikulum 2013 (2016: 50), the scientific approach 
believed to be the golden bridge and the development of attitudes, skills and knowledge of students. Scientific method refers to the techniques of investigation of one or several phenomena or symptoms, acquire new knowledge, or correcting and integrating previous knowledge. To be called scientific, search methods should be based on evidence of the object observable, empirical and

measurable principles specific reasoning. Therefore, the scientific method generally includes a series of activities of collecting data through observation or experiment, process information or data, analyze and formulate and test hypotheses.

Scientific approach was implemented in teaching some types of text in junior high school students, such as; narrative, procedure, recount, report and descriptive. However, procedure text became the only one of text types that could give a direction or way how to do or make something. This type of text can be found in food recipe in magazine, on the pack of noodle and other food, manual or instruction of electronic products, etc. Procedure text can be formed in steps how to do something and how to make something like a creative things.

Furthermore, procedure text is a text that is designed to describe how something is achieved through a sequence of actions or steps. It explains how people perform different processes in a sequence of steps. This text uses simple present tense, often imperative sentences. It also uses the temporal conjunction such as first, second, then, next, finally, and so on. Anderson and Anderson (2003:50) state that procedure text is a place of text that gives us instructions for doing something. The purpose of procedure text type is to explain how something can be done. There are many teaching media that can be used in teaching procedure text, such as

graphic, picture, video, etc. However, tutorial creatie video became one of an interesting media in teaching procedure text. Video is one of the audio visual media that can be used in teaching and learning process. It is box containing a type magnetic tape used for recording moving pictures and sound. However, the researcher believed that the implementation of scientific based approach using tutorial creative video can foster the students' reading comprehension of procedure text.

Furthermore, there were three relevant previous studies that similar to this research. The first was a research from Yuniar Reza (2008) entitled 'Improving Students' Reading Comprehension Of Procedure Text By Using Picture Series". Based on the research finding, there are improvement of students' interest and the result of the test in each cycle conducted by the teacher. In the first cycle, the amounts of students who reach the score higher than 60 were $63 \%$, while in second cycle were $87 \%$. Even though not all of the students $(100 \%)$ who reach score higher than standard score but using picture series in improving students reading comprehension of procedure text showed the significant improvement and as media picture series are effective in teaching.

Second, a thesis by Arinawati (2012), The result of this research shows that students' comprehension was improved in each cycle after they were taught using video. They 
were better in their advertisement text's reading. It was signed by their improvements in the result of each test. It means that video can be used as a medium that can help the students to understand the material. The school can make an innovation by using video as media in every lesson.

Third, a thesis by Samuel A. Perez (2014), the ten approaches described in this article can be succesfully utilized for improving the comprehension skills of most

\section{METHODOLOGY}

This research was conducted as an experiment research. The purpose of experimental research was to explore the possibility relation between cause and effect with

manipulating one independent variable to influence the others variable(s). This study attempted using tutorial video to increase students' procedure text reading ability. Both of the classes were given pre-test, treatment, the two classes would be given post test. The samples of this research were two classes with total sample 50 students at grade VIII in SMPN 4 Kota Bengkulu, they were experimental group and control group. During the experiment, the experimental group was given several treatments in period of five meetings. The reason why the researcher chose these two classes were because look like purposive sampling and the average score of English was not significant different and the same teacher taught these classes.

In this research, the researcher used reading test to know whether readers. Therefore, the researcher conducted a quasi-experimental research which enrolled two groups. It is to find out the data about the effect of implementation scientific based approach using tutorial creative video which will be employed in experiment group and scientific based approach using picture which will be employed in control group to foster students' reading comprehension of procedure text.

there is difference of students' score in reading before and after they taught by using tutorial creative video courtesy by youtube. The test is divided into two times, the first is pre-test. It was given before the treatment and the last one was posttest. It was given after the researcher has given the treatment to the class. The researcher tried out in SMPN 4 Kota Bengkulu. In this test the researcher used multiple choice forms. The researcher also used some medias in the research, there are

laptop, speaker, video, and worksheet. The data was analyzed using nomality test, homogeneity test, and independent sample t-test. Before doing the pre-test, the test of the research was tried out in class VIII in the same school. The try out was used to find the validity and item characteristics of the original draft. From 100 item test, 50 were found to be valid. The reliability index of reading instruments was 0.97 (high). Then 50 items of reading comprehension were used as the research instrument. 


\section{RESULT \& DISCUSSION Result}

In the treatment process on experiment class, the researcher applied Scientific Approach based on tutorial video in teaching reading. There were four meetings of the treatment which was done in experiment class. The researcher applied Scientific Approach using tutorial video in teaching reading. There were five reading phases of

Scientific approach. As Permendikbud No. 103 in 2014, it was stated that learning with the Scientific approach consists of five steps; observing, questioning, collecting, associating, and communicating. The teaching process will be explained as follow. There were five steps of Scientific approach. First, the step of observing. In this step, the researcher tried to activate the students' prior knowledge as well as encourage them to predict what will be learned. The researcher gave the students apperception about the text given. The students tried to observed what was learned. The tutorial video was displayed in this step. The second step was questioning. The aim of click and clunk were to teach the students to examine their reading comprehension and to identify when they have broken down in understanding. In this step, the students formulate questions about what parts of reading that were hard to understand by the students (clunks). To answer the questions of this step, the next step must be done. This step was done after showed the students a tutorial video. However, the video was similar to the text that was given to the students.

The next step was collecting, in this step, the students tried to get the
Gist. The students learned to get the gist by identifying the most important idea in a paragraph of text. The students collected as much as possible the important information about the text given by re-reading the sentence and looking for key ideas to help the students understand the word. The fourth and fifth steps of Scientific approach are the students used the data or information that has been collected to construct and answer the questions that have been prepared by the researcher related to the text given. The students learned to wrap up by formulating questions and answers after reading. they constructed their own questions to check for understanding of the passage, answer the questions, and summarize what has been learned.

Finally, the students did communicating step by submitting the students' worksheet in written.

The treatment process that was explained above had an important role in improving students' reading comprehension. Since Scientific approach helped the students to recognize their ideas in step by step of reading process, it affected the students' motivation and score in reading comprehension. The scientific approach that was applied helped the students to think scientifically. It was also helpful for the students who were hard to understanding the meaning of difficcult vocabulary. The phase in during reading; click and clunks and get the gist became the most important phase of scientific approach that was applied in this research. After doing the treatment, the researcher administered the post test at the last meeting. Moreover, in 
the treatment process, there were some students felt confuse in applying Scientific approach for the first meeting of treatment. They felt hard to follow the step by step which was explained by the researcher. However, for the next meeting of the treatment, the students looked anthusiast to learn reading, it can be seen from the students' reading score which improved from first meeting to the last meeting. Besides reading test, the questionnaire and interview were also used to know the students' interests in implementation of Scientific approach. The normality test in this research use KolmogorovSmirnov method is SPSS v.22 for windows with criteria $\rho>0.05$. The steps are analyze - descriptive statistics - explore. The output of normality test was as follow:

Table 1

Tests of Normality

\begin{tabular}{|c|c|c|c|c|c|c|}
\hline & \multicolumn{3}{|c|}{ Kolmogorov-Smirnov $^{\mathrm{a}}$} & \multicolumn{3}{|c|}{ Shapiro-Wilk } \\
\hline & stic & df & Sig. & stic ${ }^{\text {Stati }}$ & df & Sig. \\
\hline pre_control & .107 & 25 & .200 & .971 & 25 & .675 \\
\hline pre_experiment & .158 & 25 & .110 & .942 & 25 & .161 \\
\hline post_control & .209 & 25 & .116 & .923 & 25 & .110 \\
\hline post_experiment & .170 & 25 & .161 & .935 & 25 & .116 \\
\hline
\end{tabular}

a. Lilliefors Significance Correction

*. This is a lower bound of the true significance.

Based on the output of calculation, the significance of normality pre-test score in experimental and control class were 0.110 and 0.200 . It means that the data are normally distributed because more than 0.05. Moreover, the significance of normality post-test score in experiment and control class were 0.161 and 0.116 . It means that the data are normally distributed because more than 0,05 . Thus, both pre-test and post-test were distributed normally. Based on the calculation of normality, the researcher got the result that all data in pre-test both experimental class and control class have been distributed normally. The next step of the calculation was finding the pre-test and post-test homogeneity of the data by using SPSS v.16 for windows, specifically by using Kolmogorov-Smirnov method. The steps are analyze compare means - one way anova. The result of homogenity test was in the following table.

Table 2

Homogeneity Test

\begin{tabular}{|l|c|c|c|c|}
\hline \multicolumn{1}{|c|}{ Data } & $\begin{array}{c}\text { Levene } \\
\text { Statistic }\end{array}$ & df1 & df2 & Sig. \\
\hline Pre-Test & .143 & 1 & 48 & .707 \\
\hline Post-Test & .311 & 1 & 48 & .580 \\
\hline
\end{tabular}


The output of calculation shows that the significance of pre-test homogeneity result between experimental class and control class is 0.707 . It means that there is no significant difference between experimental class and control class because 0.707> 0.05. in addition, The output calculation shows that the significance of post-test homogeneity result between experimental class and control class is 0.580 which means that there is not significant difference between experimental class and control class because $0.580>0.05$. The sumary of hypothesis testing result of post-test was displayed in the table below:

Table 3

Summary of Hypothesis Testing on Post-Test

\begin{tabular}{|l|c|c|c|l|}
\hline \multicolumn{1}{|c|}{ Post_Test Score } & T & $\begin{array}{c}\text { Sig. } \\
\text { (2-tailed) }\end{array}$ & $\begin{array}{r}\text { Mean } \\
\text { Difference }\end{array}$ & Conclusion \\
\hline Whole Reading Comprehension & -3.372 & .001 & 8.32 & Significant \\
\hline Finding General Information & -3.041 & .004 & 3.96 & Significant \\
\hline Finding Specific Information & -3.139 & .003 & 3.92 & Significant \\
\hline Learning from Text & 2.870 & .006 & 2.42 & Significant \\
\hline Integrating Information & 2.737 & .008 & 2.20 & Significant \\
\hline
\end{tabular}

Regarding to table 3, there was a significant difference on students' reading comprehension after implementing Scientific approach based on Tutorial Video. It can be seen on the table that, the sig. (2tailed) $<0,05$ for whole reading comprehension, finding general information, finding specific information, learning from text, and integrating information. Even it was significant, the mean difference of learning from text and integrating information aspects were only 2.42 and 2.20 with sig.(2-tailed) $=0,06$ and 0,08 . The small number of mean difference of these two aspects were because the treatment process of using tutorial video through scientific learning did not focus on learning

\section{Discussion}

The result showed that scientific approach with tutorial video is effective to improve students' reading comprehension at grade VIII students in SMPN 4 Kota Bengkulu. from text and integrating information dominantly, for example; memorize main ideas and write the text. However, using tutorial video through scientific learning can improve the students reading comprehension in the aspect of finding general and specific information better since using scentific learning can help the students to explore the information from the text. To be concluded, Scientific approach based on Tutorial Video was effective to improve students' reading comprehension on the aspect of finding general

information, finding specific information, learning from text, and integrating information.

It was proven by the results of posttest in which the experiment class gained 8.32 higher than the control class. Moreover, Scientific approach with tutorial video is effective to 
improve four aspects of reading comprehension, namely; reading for finding general information, reading for finding specific, reading to integrate infomation, and reading to learn from text. This is supported by Mulyana(2004) who claimed that

scientific method has three characteristics, namely; centered on student, involves the science process skills in constructing the concept, law and principle, involves the cognitive processes of potential in stimulating the development of

intellect, especially high-level thinking skills of students and be able to develop the character of students. It means that both two approaches apparently buildsome communication skills.In learning activity, SAis applied through five steps: observing,questioning, experimenting, associating andnetworking or communicating while GBA is conducted through building knowledge of field, modeling of text, join construction and independent construction.

Moreover, Baldwin stated that there are six learning objectives of scientific approach, they are to improve the ability of intellect, especially high-level thinking skills of students, to establish the ability of students to solve a problem systematically, the creation of the conditions of learning in which students feel that learning is a necessity, tbtaining a high learning result, to train students in communicating ideas, especially in writing a scientific article, and to develop students ${ }^{\text {ee }}$ character. This theory supported the result of the research which revealed that Scientific approach improved the students' reading comprehension in finding general information and specific information by establishing high-level thinking skills of students. Related to the use of tutorial video, there are also some theory which supported the result of this study as Harmer (2003) states that to help students comprehend the text, there are many media that can be used. One of them is video. Video allows teachers to not only tell students what they need to learn from a specific lesson, but show them examples that helps develop understanding. Video can be used in a variety of ways to enhance any lesson plan or subject. Sharing that video could be enhance simulations, not only because it could provide feedback when students could be watched themselves and evaluate their performance, but also because the presence of a video helped to make students feel more realistic.

Furthermore, Harmer (1998) pointed out four advantages of using video. The first is students can get to see the language in use. By seeing language in use, students can see a whole lot of paralinguistic behaviour. Second, the students can pick up a range of cross - cultural clues. The film or video allows students to entry into a whole range of other

communication worlds, and unspoken rules of behaviour in social and business situation are easier to see. Furthermore, film or video can be used as main focus of a lesson sequence or as parts of other language sequence. The last is video or film associates with relaxation. Students have to be provided by good viewing and listening task, so that they may give their full attention to what they are hearing and seeing. Students can watch a huge range of film clips or short video on the internet at sites such as You Tube. 
This research result also in line with the previous studies. First, a research from Septiana (2017) who found that the Implementation of the Scientific Approach in the Teaching of Reading Comprehension for the Tenth Grade Students of SMAN 2 Karanganyar was good, because was appropriate with the regulation, and in applying scientific approach, the teacher used five phase, those are

observing, questioning, experimenting, associating, and communicating. The teacher used authentic assessment in the evaluation. It covers three aspects namely, students ${ }^{\text {ee }}$ attitude, students ${ }^{\text {ee }}$ knowledge and students se skill. Based on the second meeting, the English teacher uses writing test to assess the cognitive aspect of the students. Another previous study was from Ahmad (2015) who found that there was significant improvement from attempting the scientific approach. Similar to this research result, scientific approach is effective to improve students' reading comprehension.

This research result also in line with Arinawati (2012) who found that students' comprehension was

\section{CONCLUSION}

There were two conclusions of this research, which was about the effectiveness of applying scientific approach based on tutorial video at grade VIII SMPN 4 Kota Bengkulu;

(1) Scientific approach based on tutorial video affected students' reading comprehension in whole improved in each cycle after they were taught using video. They were better in their advertisement text's reading. It was signed by their improvements in the result of each test. It means that video can be used as a medium that can help the students to understand the material. The school can make an innovation by using video as media in every lesson.Furthermore, this study has different result from another studies, for instance; PQRST, CORI, Reciprocal Reading, SMART, and GIST strategy which failed on improving all various aspects by using another teaching reading. However, the small class taken as the sample and kinds of text used in this research becomes the limitation of this research since it was only conducted in limited time and place of research. The researcher also suggested for English teachers to determine the kind of text used. It must be appropriate to the level of students. Thus, further research studies can be conducted to compare the effects of using Scientific approach with tutorial video on students' reading skill for senior high school level.

reading comprehension;

Scientific approach based on tutorial video affected students' reading comprehension in various aspects of reading comprehension, namely; finding general information, finding specific information, integrating information, and learning from text. 


\section{REFERENCES}

Arikunto,S. (2002). Prosedur penelitian suatu pendekatan praktik. Jakarta; Indonesia. Rineka Cipta

Anderson, M. And Anderson. (1998). Text types in English. Sydney: Mc. Millan Education

Anderson, Mark and Anderson Kathy. (2003). Text type in English 2. Sydney: Mackmillan

Broek and Espin. (2012). Speaking up for vocabulary: Reading skill differences in young adults. Journal of Learning Disabilities, 40(3), 226-243.

Coolidge, F. I. (2000). Statistics: $a$ general introduction. London; UK. SAGE Publication Ltd

Colough. (2002). Improving reading skill. Newyork: The Guilford Press

Francois. (1981). Developing reading skill a practical guide to reading comprehension exercise. UK: Cambridge University Press

Harmer. (2001). The practice of English language teaching. Camridge: Logman

Jeremy. (1998). How to teach English. England: Longman

Jo McDonough and Christopher Shaw. (2003). Materials and methods in ELT: A Teacher's

Guide, UK: Blackwel Publishing

Lems, Kristin, dkk. (2010). Teaching reading to English learners: insight from linguistics. New York;NY. The Guilford Press
MacLeod. (2003). Types of reading, at Oxford Learner's Pocket Dictionary. New York: Oxford University Press

Mark Anderson and Kathy Anderson. (1998). Text types in English 3. Australia; Mcmillan Education Ltd

Nunan, D. (1992). Practical English language teaching of reading. Singapore: The McGrowHill Education (Asia).

Pachler, Norbert and Ana Redondo. (2007). A Practical guide to teaching modern foreign language in secondary school. New York; NY. Routledge.

Patricia L. And Grabe. (2002). "Reading", on norbert schmitt (ed. an introduction to applied) linguistics. New York; NY. Oxford University Press

Richard R. Day and Julian. (1998). Extensive reading in the second language classroom. United State of America; USA. Cambridge University Press

Sudjana, N. (2002). Metode statistika. Bandung;

Indonesia. Tarsito

Sugiyono. (2001). Metode penelitian. Bandung; Indonesia. Alfabeta Ur, Penny. (2004). A couse in learning teaching.

CamridgeUniversityVanden Broek \& Espin. (2012).

Reading Comprehension. New York; NY. Amy L. Moore, M.A 